Egyptian Journal of Aquatic Biology \& Fisheries

Zoology Department, Faculty of Science,

Ain Shams University, Cairo, Egypt.

ISSN $1110-6131$

Vol. 22(5): $563-572(2018)$

www.ejabf.journals.ekb.eg

\title{
Effect of Environmental Pollution on Gonads Histology of the Nile Tilapia, Oreochromis niloticus from Lake Manzala, Egypt
}

\author{
Hala A. A. Mansour ${ }^{1}$; Mohamed A. H. El-kady ${ }^{2}$; *Ali H. Abu Almaaty ${ }^{3}$ and \\ Amal M. Ramadan ${ }^{4}$ \\ 1,2- Laboratory of Genetics, Aquaculture Division, National Institute of Oceanography and \\ Fisheries, Egypt. \\ 3- Zoology Department, Faculty of Science, Port Said University, Port Said, Egypt. \\ 4- Laboratory of Fish Reproduction and Spawning, Aquaculture Division, National \\ Institute of Oceanography and Fisheries, Egypt. \\ E-mail: ali_zoology_2010@yahoo.com
}

\section{ARTICLE INFO}

\section{Article History:}

Received: 1 Nov., 2018

Accepted: 5 Dec. 2018

Online: Dec. 2018

Keywords:

Histology

Oreochromis niloticus

Gonads

Pollution

Lake Manzala

\begin{abstract}
Lake Manzala suffers from severe pollution of complex composition from different sources of industrial, agricultural and sewage facilities from the surrounded governorates. The objective of this research was aiming to study the effects of some environmental polluted effluents at five locations of Lake Manzala on the gonads of Oreochromis niloticus. The histological study of testes of $O$. niloticus showed decreased number of seminiferous tubules with some degenerative changes. They appeared empty from different spermatogenic cells (primary and secondary spermatocytes). Moreover the interstitial cells were collapsed and appeared in all seminiferous tubules. The ovaries presents a deformation from their ideal shapes, thickening and detaching of the membrane of all stages of oocytes and two types of non-bursting atresia in oocytes were markedly appeared. We recommended improving water quality control and the environmental monitoring is essential at Lake Manzala.
\end{abstract}

\section{INTRODUCTION}

Fish are considered as bioindicator and play an important role in assessing potential risks related to pollution (Lakra and Nagpure, 2009; Magar and Bias, 2013). Exposure of fish organs to pollutants can lead to acute or chronic toxicity, in particular, the reproductive organs which then cause reproductive failure. The health of the organism's reproductive process is an important indicator of the organism to be able to sustain itself (Zulfahmi et al., 2018).

Nile tilapia, Oreochromis niloticus is a fish of economic importance in tropical and subtropical countries and it highly consumed by a large sector of Egyptians. This fish is more abundant throughout the year than much other Egyptian fish. It is an important and cheap source of the animal protein (Kime et al., 1996; El-Badry, 2010).

Lake Manzala, is the largest Lake of the northern delta wetlands of Egypt. 
Industrial effects have modified it to turn into one of the most polluted Lakes in this country. It is considering highly fish production that monopolized about half of the production of northern Lakes in Egypt (GAFRD, 2012).

Histopathological biomarkers or cellular changes in tissues such as gill, liver, kidney, and spleen have received much attention in assessing the effects of environmental stress (Spies et al., 1996; Teh et al., 1997; Blazer, 2002). Historically, much less attention has been focused on endocrine, neural and gonadal histology; all systems that influence reproduction. The recognition that many environmental chemicals may act as endocrine disruptors and hence influence reproduction has led to the interest in assessing reproductive health of wild aquatic animals (Goodbred et al., 1997; Rolland et al., 1997; Jobling et al., 1998; Kendall et al., 1998).

Water pollution occurs when pollutants are directly or indirectly discharged into water bodies (e.g. lakes, rivers, oceans, aquifers, and groundwater) without adequate treatment to remove harmful compounds. Water pollution affects plants and organisms living in these bodies of water (Authman, 2008).

It is possible that environmental toxicants may increase the susceptibility of aquatic animals to various diseases by interfering with the normal functioning of their immune, reproductive and developmental processes (Couch and John, 1978; Kaoud and El-Dahshan, 2010).

The present work aimed to study the effects of different discharges of pollution at five locations of Lake Manzala on the gonads of Nile tilapia, O. niloticus.

\section{MATERIALS AND METHODS}

\section{Study area}

The sampling sites of Lake Manzala are demonstrated in Fig. (1). The sites are as follow: 1: El-Gamil (G), 2: El-Bashtir (B), 3: El-Serw (S), 4: El-Temsah (T). At the same period of time, samples of studied fish with comparable both weight and conditions were collected from the reference site (5) which is close to El-Matariya Research Station for Aquatic Resources.

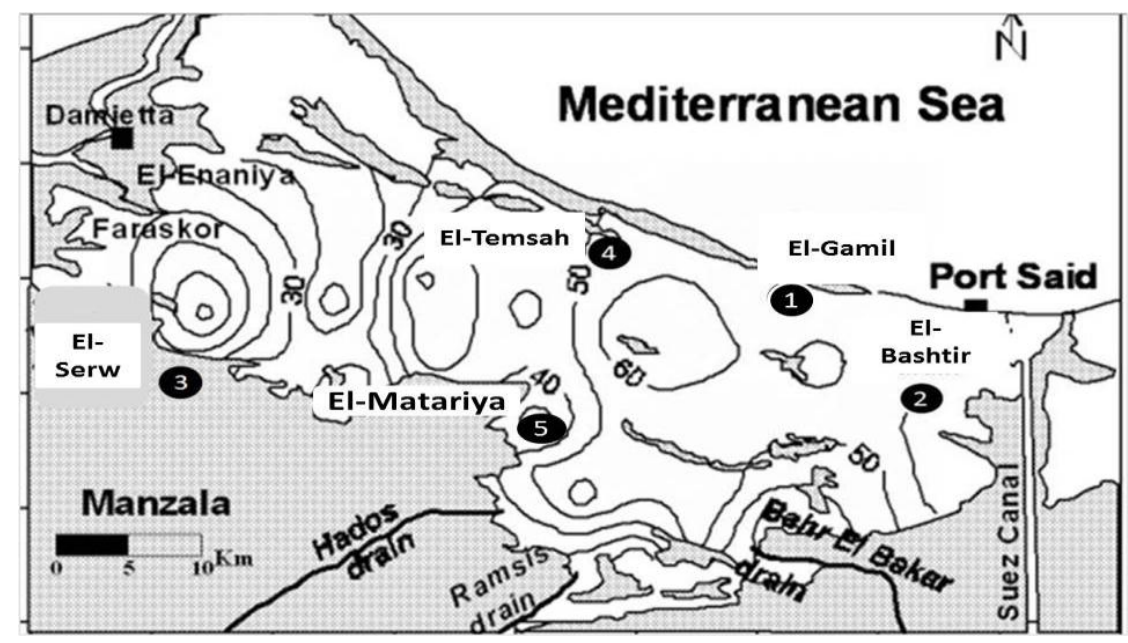

Fig. 1: Map of Lake Manzala showing the sampling sites

\section{Histological examination of gonads}

To study the direct effects of the different discharges at Lake Manzala, adult samples of Oreochromis niloticus were collected from the studied sites and brought alive to the laboratory. After dissecting the fish, gonads (testes and ovaries) were 
immediately removed and fixed in Bouin's solution for $24 \mathrm{~h}$. The tissues were routinely dehydrated in an ascending series of alcohol, cleared in xylene and embedded in paraffin wax. Sections of 5-6 $\mu \mathrm{m}$ thick were cut, processed and stained with hematoxylin and eosin $(\mathrm{H}$ and $\mathrm{E})$ and then, Canada balsam was poured and covered with a cover glass. They were examined and photographed under light microscope unit (Leica microscope). (Mohamed, 2009; Shobikhuliatul et al., 2013).

\section{RESULTS}

\section{Gonads histology of $O$. niloticus at the reference site}

The histological sections of testis and ovary of the reference site are shown in Fig. (2). Firstly, the ideal general structure of testes having an elongated paired organs attached to the dorsal body wall. Fig. (2a) is showing the ideal structure of the testis as the following: spermatogonia; it is the first spermatogenic stage in the testis. Spermatogonia were often noticed as nests. Primary spermatocytes are produced by the mitotic division of spermatogonia. These cells are constructed by meiotic division and distinguished by homogeneously stained nuclei into secondary spermatocytes. The subsequent division of secondary spermatocytes produced spermatids. Spermatids are slightly smaller in diameter than secondary spermat-ocytes. Spermatids with certain metamorphosis form spermatozoa. Finally, the sperm is acquired the energy to be mobile in the seminal fluid. This is the final product of the process of spermatogenesis.

Secondly, the general structure of the ovary is a paired organ, consisting of two ovarian lobes which are separated by a septum. Both lobes are joined near the urogenital pore. Microscopically as shown in Fig. (2b), it has several components as the following: oogonia; are small round cells with a comparatively clear zone of cytoplasm.

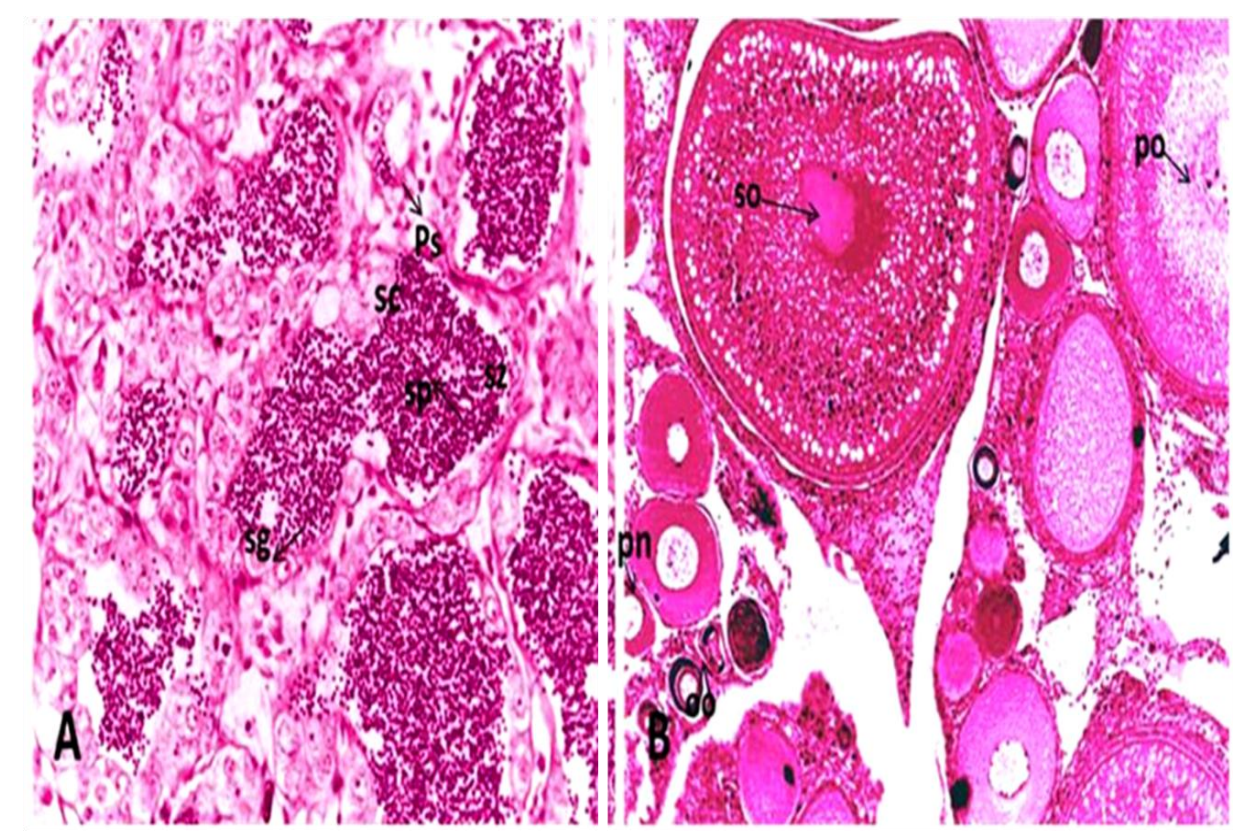

Fig. 2: (A) T.S. of the testis of $O$. niloticus at the reference site showing ideal spermatogenesis process; the seminiferous tubules contains many spermatogonia (sg), primary spermatocytes (ps), secondary spermatocyte (sc), spermatids (sp) and spermatozoa (sz). (B) T.S. of the ovary of $O$. niloticus at the reference site showing ovarian tissue with oogenesis process in it. Oogonia (oo) divided into prenucleus (pn) then into numerous primary follicles containing the oocytes (po), then into secondary oocyte (so). 
The prenucleus stage of the oocytes with the early and late stage are varying in size and number of nuclei. On further maturation, the oocytes entering yolk vesicle stage (vacuolization stage) in which deposition of yolk and fat globules starts which increase the size of maturing egg. The cytoplasm loses its basophilic nature and became fully occupied with yolk granules. At the yolky stage, the vacuoles become connected to each other and nucleus began to liberate its content into the cytoplasm and then starts to migrate to the animal pole. In the final stage the nucleus increased in size with a numerous number of nucleoli to give primary then secondary oocyte which is the mature stage of ova.

\section{Effects of the different effluents of pollution on the gonads histology of $O$. niloticus}

The results of the studied sites showed that gonads were affected by the different effluents of pollution, as the following:

As shown in Fig. (3a), the testis of Nile tilapia at El-Temsah site has lost its ideal shape of seminiferous tubule and has residuals of primary and secondary spermatocytes. The remarkable feature of the ovary of Nile tilapia at the same site is the thickening of the membrane of all stages of oocytes (Fig. 3b). In spite of the lowest rates of pollution at this site, according to our study (data not shown), the gonads of $O$. niloticus are clearly suffering from deformation from their ideal shapes.

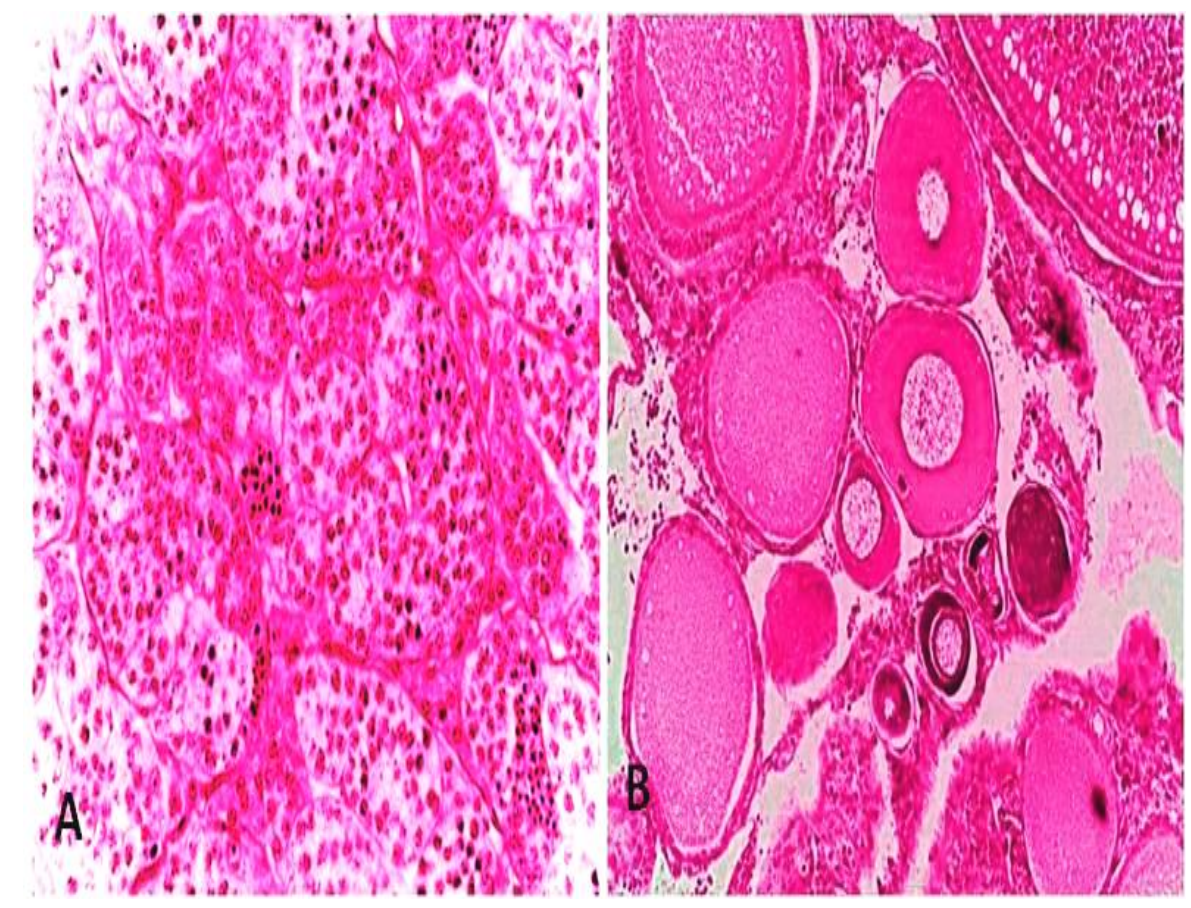

Fig. 3: (A) T.S. of the testis of $O$. niloticus from El-Temsah site showing that seminiferous lobules lost its identity, have residual of primary and secondary spermatocytes. (B) T.S. of the ovary of $O$. niloticus from El-Temsah site illustrating thickened membrane of oocyte and atretic oocytes in the different stages.

The results illustrated in Fig. (4a) showing the irregular shape of seminiferous tubules of the testis at El-Gamil site, while the detaching the cell membrane from oocyte body was obviously appeared in the ovary (Fig. 4b). As shown in Fig. (5a), the testis of Nile tilapia at El-Bashtir site, showed also the irregular shape of seminiferous tubules and the presence of residuals of spermatocytes have clearly appeared. On the other hand, the ovary (Fig. 5b) has a thick cell membrane. 


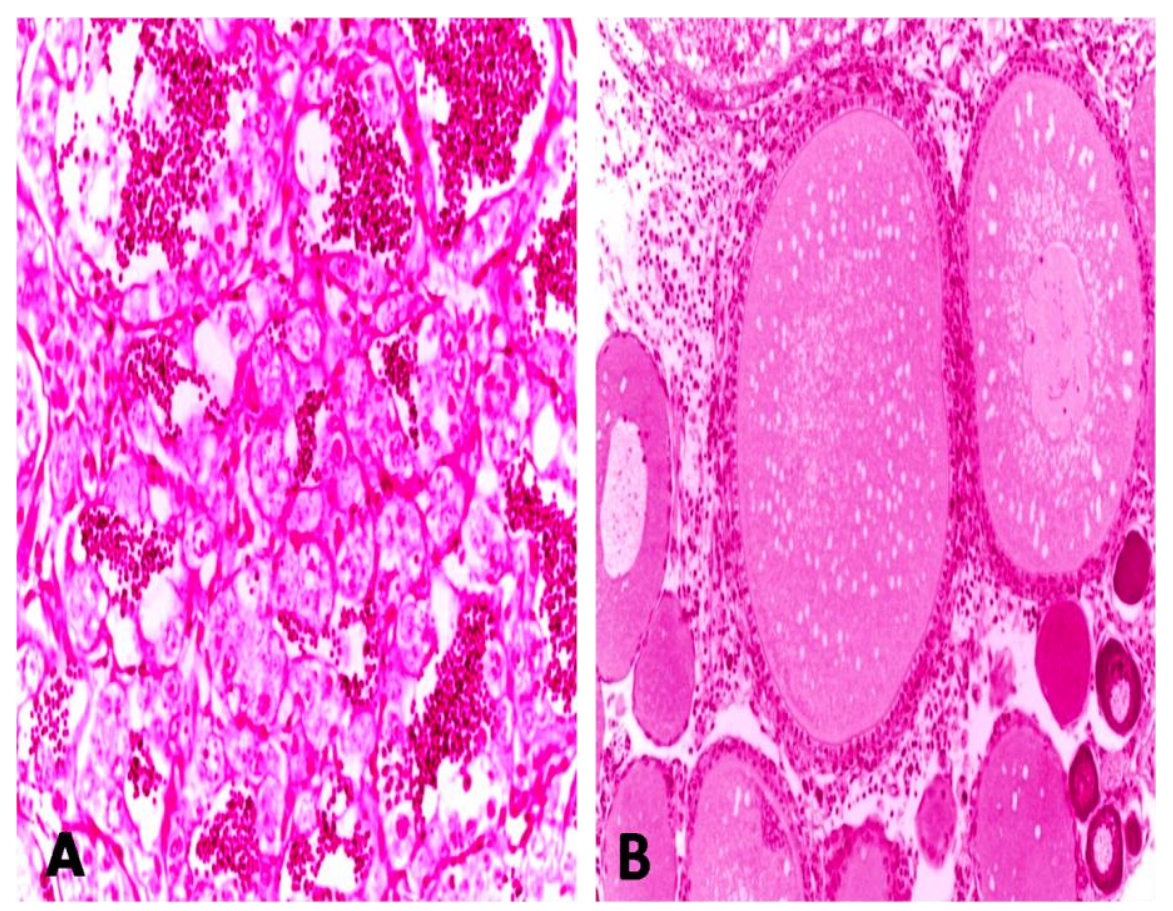

Fig. 4: (A) T.S. of testis of $O$. niloticus at El-Gamil site, illustrating more spermatocytes separated in the testis and irregular shape of seminiferous tubules. (B) T.S. of the ovary of O. niloticus at El-Gamil site, illustrating separated membrane from oocyte, atretic prenucleus cells and condensing of oocytes contents.

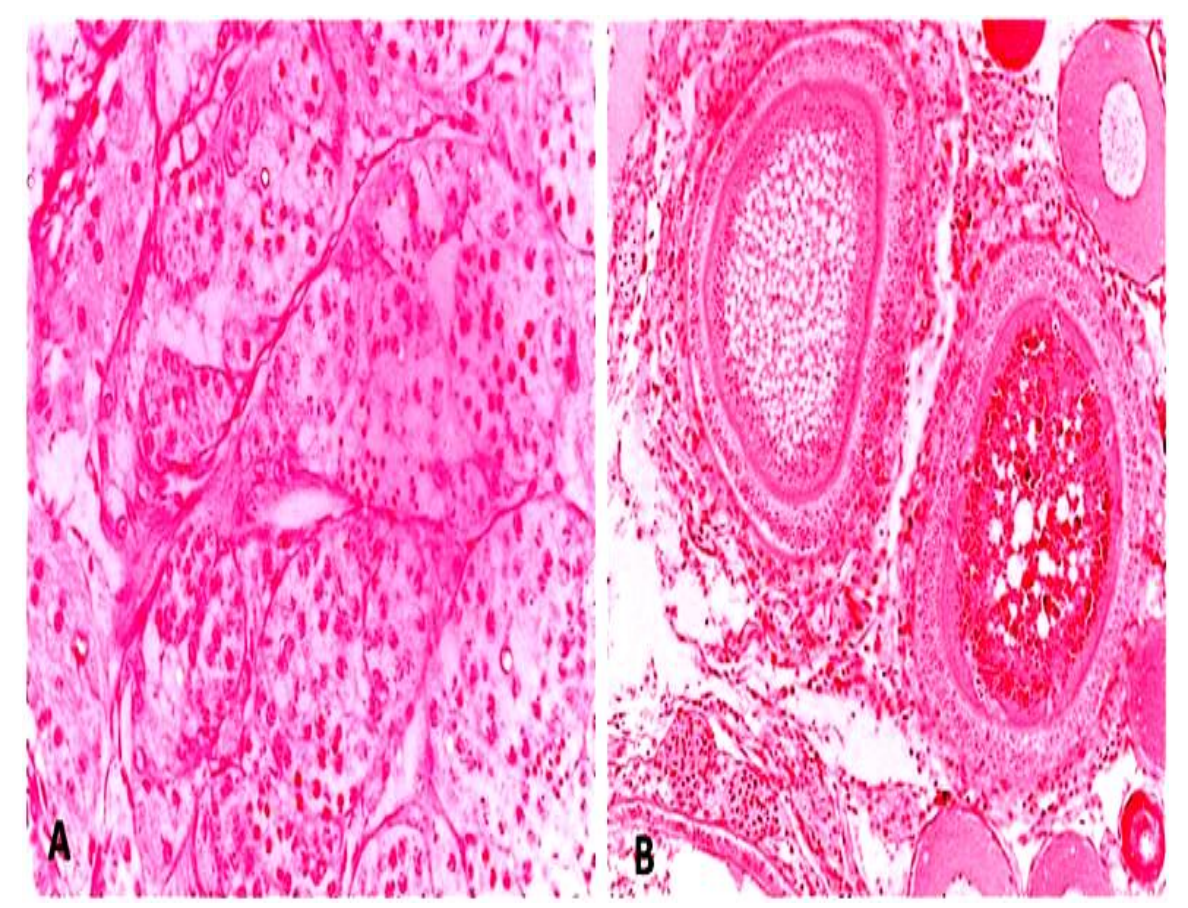

Fig. 5: (A) T.S. of the testis of Nile tilapia from El-Bashtir site, that showing no ideal shape of seminferous lobule, residual of spermatocytes. (B) T.S. of the ovary of Nile tilapia from ElBashtir site, that showing thickened cell membrane, many vacuoles in oocytes are found.

Finally, results illustrated in Fig. (6a), showed the deformations of testis at ElSerw site was represented with the empty lumen from spermatocytes and the residuals of spermatozoa are found, while in the ovary, the two types of non-bursting 
atresia in the oocytes were clearly appeared and the thickening of cell membrane of oocyte was detected (Fig. 6b).

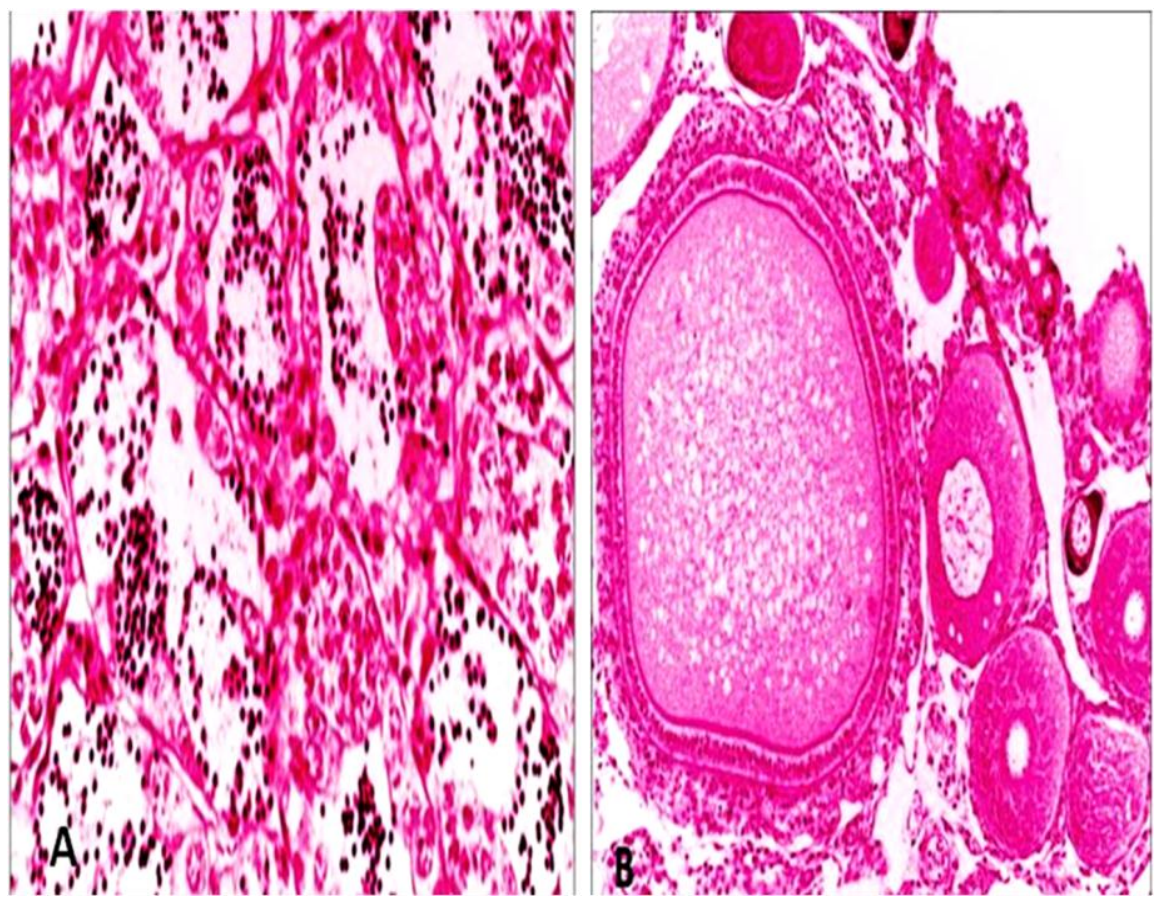

Fig. 6: (A) T.S. of the testis of $O$. niloticus at El-Serw site, showing empty lobules from spermatozoa and presence of residuals of spermatocytes in the seminiferous tubules. (B) T.S. of the ovary of $O$. niloticus at El-Serw site, showing thickened membrane of oocyte, atresia in some of cells from different stages and phagocytes appeared on the membrane of oocyte.

\section{DISCUSSION}

The analysis of reproductive functions is a key factor in determining the dynamics of fish populations (Mekkawy and Hassan, 2011; Ojaveer et al., 2015). The presence of pollutants is one of many environmental factors that can result in a dangerously compromised fish reproduction system. Several other studies have proven that exposure to pollutants can lead to a decline in gonadosomatic index (Gerbron et al., 2014), shrinking oocyte diameter (Alquezar et al., 2006), dysfunctional hormone reproduction (Ebrahimi and Taherianfard, 2011), alteration in reproductive behavior (Bertram et al., 2015) and increased abnormality of fish larvae (Zhang et al., 2016).

In Egypt, the pollution of the aquatic habitats seems to be an inevitable problem. In recent years, more toxic compounds are being increasingly detected in the aquatic ecosystem (Khare and Singh, 2002). El-Morshedi et al., (2014) reported that the environmental impacts of Lake Manzala caused a pronounced decline in gonad activity of the studied fish, where was reflected clearly by decreasing sperm in ripe testes and ripe oocytes degeneration (atresia). Also, Luzio et al., (2016) reported the disruption of the sexual development; inducing masculinization and causing severe pathological alterations in testis, such as the enlargement of sperm ducts, interstitial changes, asynchronous development and detachment of basal membrane, while in ovaries, there were atretic oocytes.

According to Roberts, (2012) indicated that water pollution has a serious inhibitory effect in fish reproduction. The different pollutants such as industrial and agricultural wastes, pesticides and also different types of bacteria have 
histopathological effects on the reproductive tissues of fish gonads (Jhonson et al., 1991; Lye et al., 1998).

Although El-Temsah site that far from any kind of discharges of pollution of the Lake, but the deformation of gonads of $O$. niloticus from their ideal shapes was found to indicate the effect of the pollution on the different regions of Lake Manzala. The deformations of ovary and testis at the other locations were sharply noticed. This is may be attributed to the presence of petroleum companies close to El-Gamil site, or the presence of multiple kinds of pollutants (industrial, sewage, and agricultural) at El-Bashtir site which is close to Bahr El-Baquar drain, while the deformation of gonads at El-Serw site may be as a result of great amount of agricultural pollution of pesticides which is close to El-Serw drain.

In the present research, the results of histological examination of gonads obviously proved that the pollution had their great effect on the gonads of $O$. niloticus. Its effect appeared as a disruption in gonadal development. It comes in agreement with a study for fish inhabiting polluted water by Al-Halani, (2018).

The different pollutants such as industrial and agricultural wastes, pesticides and heavy metals have histopathological effects on the reproductive tissues of fish gonads (Pedlar et al., 2002; Hanna et al., 2005). These effects may disturb the development of germ cells and may reduce the ability of the fish to reproduce (Mehanna, 2005; Khillare et al., 2017). Also, the testes of the fish collected from the polluted water revealed an impairment of spermatogenesis and lobular structures and the suppressing sperm production was observed by previous studies (Jaensson et al., 2007; Shobikhuliatul et al., 2013).

The effects of pollutants on fish reproduction have been investigated by numerous researchers who confirmed adverse impacts on fish organs and especially their reproductive capacities. For instance, follicular atresia, which is caused by exposure to pollutants, was reported by Molina et al., (2013). A similar study conducted by Senarat et al., (2017) further confirmed the relationship between pollutants and the rise of follicular atresia, which was caused by a reduction of activities of hormone gonadotropin (GTH) and other estrogen hormones. According to Sridevi et al., (2015), the disorders that occurred in the reproductive hormone led to reduction (degeneration) of yolk size. Patiño and Sullivan, (2002) stated that oocytes contain various regulatory compounds such as various lipophilic hormones and steroids, antibodies, vitellogenin receptors, enzymes, and various other active compounds. Exposure to pollutants results in dysfunction of the reproductive hormone which then affects the vitellogenin receptors, i.e. disruption in the oocytes (Kime, 1999).

\section{CONCLUSION}

The results of histological examination of gonads obviously showed that the stresses had their great effects on the gonads of O. niloticus. Also, the present study documented that improvement of water quality control and periodically environmental monitoring are necessary for Lake Manzala water. In Egypt, although there are a marked reduction in pollution contents in Lake Manzala when compared to the past few years, more governmental efforts still needed to control environmental pollution and improve its water quality. 


\section{REFERENCES}

Al-Halani, A.A. (2018). Effect of seasonal changes on physiological and Histological Characteristics of Nile tilapia (Oreochromis niloticus) Inhabited Two Different Freshwater Habitats. Int. J. Modern Biol. Med., 9(1): 9-28.

Alquezar, R.; Markich, S.J. and Booth, D.J. (2006). Effects of metals on condition and reproductive output of the smooth toadfish in Sydney estuaries, southeastern Australia. Environ. Pollut., 142: 116-122.

Authman, M.M.N. (2008). Oreochromis niloticus as a biomonitor of heavy metal pollution with emphasis on potential risk and relation to some biological aspects. Global Veterinaria, 2(3): 104-109.

Bertram, M.G.; Saaristo, M.; Baumgartner, J.B.; Johnstone, C.P.; Allinson, M.; Allinson, G. and Wong, B.B. (2015). Sex in troubled waters: widespread agricultural contaminant disrupts reproductive behavior in fish. Horm. Behav. 70: 85-91.

Blazer, V.S. (2002). Histopathological assessment of gonadal tissue in wild fishes. Fish Physiology and Biochemistry, 26(1): 85-101.

Couch, C. and John, A. (1978). Diseases, parasites, and toxic responses of commercial penaeid shrimps of the Gulf of Mexico and South Atlantic Coasts of North America. EPA-600/J-78-072. U.S. Fish and Wildlife Service. Fishery Bulletin ,76: 1-44. (ERL, GB 283).

Ebrahimi, M. and Taherianfard, M. (2011). The effects of heavy metals exposure on reproductive systems of cyprinid fish from Kor River. Iran. J. Fish. Sci., 10: 13-26.

El-Badry, D. A. (2010). Studies on some diseases in catfish (Clarias garirpinus) in Dakahlia Governorate. M. Sc. Thesis, Faculty of Science, Mansoura University, Egypt.

El-Morshedi, N.; Kizilbash, N.A.; Abdeen, A.; El-Shebbly, A. and El-Berri, A. (2014). Histological and Histochemical Changes on Gonads of Sea Bass Fish as Consequence of Water Pollution. IOSR Journal of Environmental Science, Toxicology and Food Technology, 8(9): 13-19.

GAFRD (General Authority for Fish Resources Development), (2012). Year-Book of fishery statistics in Egypt, Cairo.

Gerbron, M.; Geraudie, P.; Fernandes, D.; Rotchell, J.M.; Porte, C. and Minier, C. (2014). Evidence of altered fertility in female roach (Rutilus rutilus) from the River Seine (France). Environ. Pollut., 191: 58-62.

Goodbred, S.L.; Gilliom, R.J.; Gross, T.S.; Denslow, N.P.; Bryant, W.L. and Schoeb, T.R. (1997). Reconnaissance of $17 \beta$-estradiol, 11-ketotestosterone, vitello-genin, and gonadal histopathology in common carp of United States streams: Potential for contaminant-induced endocine disruption. U.S. Geological Survey Open-File Report 96-627, Sacramento, California, 47.

Hanna, M.I.; Shaheed, I.B. and Elias, N.S. (2005). A contribution on chromium and lead toxicity in cultured Oreochromis niloticus. Egyptian Journal of Aquatic Biology and Fisheries, 9:177-209.

Jaensson, A.; Scott, A.P.; Moore, A.; Kylin, H. and Olsén, K.H. (2007). Effects of a pyrethroid pesticide on endocrine responses to female odours and reproductive behaviour in male parr of brown trout (Salmo trutta L.). Aquatic toxicology, 81(1): $1-9$.

Jobling, S.; Nolan, M.; Tyler, C.B.; Brighty, G. and Sumpter, J.P. (1998). Widespread sexual disruption in wild fish. Environ. Sci. Technol., 32: 2498-2506.

Kaoud, H.A. and El-Dahshan, A.R. (2010). Bioaccumulation and histopathological alterations of the heavy metals in Oreochromis niloticus fish. Nature and science, 8(4): 147-156. 
Kendall, R.J.; Dickerson, R.I.; Giesy, J.P. and Suk, W.A. (1998). Principles and processes for evaluating endocrine disruption in wildlife. Society for Environmental Toxicology and Chemistry Press, Pensacola, FL: 515.

Khare, S. and Singh, S. (2002). Histopathological lesions induced by copper sulphate and lead nitrate in the gills of fresh water fish Nandus nandus. J. Ecotoxicol. Environ. Monit., 12: 105-111.

Khillare, K.; Khillare, Y.K. and Wagh, U. (2017). Histological Changes in Gonads of Fresh Water Fishes Due To Heavy Metal Pollution. World Journal of Pharmacy and Pharmaceutical Sciences, 6(7): 601-609.

Kime, D.E.; Ebrahimi, M.; Nysten, K.; Roelants, I.; Moore, H.D. and Ollevier, F. (1996). Use of computer assisted sperm analysis (casa) for monitoring the effects of pollution on sperm quality of fish; application to effects of heavy metals. Aquatic Toxicology, 36 (1): 223-237.

Kime, D.E. (1999). A strategy for assessing the effects of xenobiotics on fish reproduction. Sci. Total Environ, 225: 3-11.

Lakra, W.S. and Nagpure, N.S. (2009). Genotoxicological studies in fishes: a review. Indian J. Anim. Sci., 79: 93-97.

Luzio, A.; Matos, M.; Santos, D.; Fontaínhas-Fernandes, A.A.; Monteiro, S.M. and Coimbra, A.M. (2016). Disruption of apoptosis pathways involved in zebrafish gonad differentiation by $17 \alpha$-ethinylestradiol and fadrozole exposures. Aquatic Toxicology, 177: 269-284.

Lye, C.M.; Frid, C.L.J. and Gill, M.E. (1998). Seasonal reproductive health of flounder Platichthys flesus exposed to sewage effluent. Marine Ecology Progress Series, 170: 249-260.

Magar, R.S. and Biase, U.E. (2013). Histopathological impact of malathion on the ovary of the freshwater fish Channa punctatus. International Journal of Environmental Science, 2(3):59-61.

Mehanna, S.F. (2005). Population dynamics and management of the Nile Tilapia $(O$. niloticus) in Wadi El-Raiyan Lakes, Egypt. Afr. J. Biol. Sci., 1:79-88.

Mekkawy, I.A. and Hassan, A.A. (2011). Some reproductive parameters of Synodontis schall (Bloch and Schneider, 1801) from the River Nile, Egypt. J. Fish. Aquat. Sci., 6: 456.

Mohamed, F.A.S. (2009). Histopathological studies on Tilapia zillii and Solea vulgaris from Lake Qarun, Egypt. World Journal of Fish and Marine Sciences, 1(1): 29-39.

Molina, A.M.; Lora, A.J.; Blanco, A.; Monterde, J.G.; Ayala, N. and Moyano R. (2013). Endocrine-activ compound evaluation: Qaualitative and quantitative histomorphological assessment of zebrafish gonad after bisphenol-A exposure. Ecotoxicol. Environ. Saf., 88: 155-162.

Ojaveer, H.; Tomkiewicz, J.; Arula, T. and Klais R. (2015). Female ovarian abnormalities and reproductive failure of autumn-spawning herring (Clupea harengus membras) in the Baltic Sea. ICES J. Mar. Sci., 72: 2332-2340.

Patiño, R. and Sullivan, C.V. (2002). Ovarian follicle growth, maturation, and ovulation in teleost fish. Fish Physiol. Biochem., 26: 57-70.

Pedlar, R.M.; Ptashynski, M.D.; Evans, R. and Klaverkamp, J.F. (2002). Toxicological effects of dietary arsenic exposure in Lake Whitefish (Coregeonus clupeaformis). Aquatic Toxicology, 57: 167-189.

Roberts, R.J. (2012). Fish pathology. John Wiley and Sons.

Rolland, R.M.; Gilbertson, M. and Petersen, R.E. (eds.). (1997). Chemically induced alterations in functional development and reproduction of fishes. Proceedings from a session at the Wingspread Conference Center, July 1995, Racine, WI. Society of Environmental Toxicology and Chemistry Press, Pensacola, FL: 224. 
Senarat, S.; Jiraungkoorskul, W. and Kettratad, J., (2017). Ovarian histology and reproductive health of short mackerel, Rastrelliger brachysoma (Bleeker, 1851), as threatened marine fish in Thailand. Songklanakarin. J. Sci., Technol: 39.

Shobikhuliatul, J.J.; Andayani, S.; Couteau, J.; Risjani, Y. and Minier, C. (2013). Some aspect of reproductive biology on the effect of pollution on the histopathology of gonads in Puntius javanicus from Mas River, Surabaya, Indonesia. Journal of Biology and Life Science, 4(2): 191-205.

Spies, R.B.; Stegeman, J.J.; Hinton, D.E.; Woodin, B.; Smolowitz, R.; Okihiro, M. and Shea, D. (1996). Biomarkers of hydrocarbon exposure and sublethal effects in embiotocid fishes from a natural petroleum seep in the Santa Barbara Channel. Aquat. Toxicol., 34: 195-219.

Sridevi, P.; Chaitanya, R.K.; Prathibha, Y.; Balakrishna, S.; Dutta-Gupta, A. and Senthilkumaran, B. (2015). Early exposure of 17a-ethynyl-estradiol and diethylstilbestrol induces morphological changes and alters ovarian steroidogenic pathway enzyme gene expression in catfish, Clarias gariepinus. Environ. Toxicol., 30: 439-451.

Teh, S.J.; Adams, S.M. and Hinton, D.E. (1997). Histopathological biomarkers in feral freshwater fish populations exposed to different types of contaminant stress. Aquat. Toxicol., 37: 51-70.

Zhang, Q.F.; Li, Y.W.; Liu, Z.H. and Chen, Q.L. (2016). Exposure to mercuric chloride induces developmental damage, oxidative stress and immunotoxicity in zebrafish embryos-larvae. Aquat. Toxicol., 181: 76-85.

Zulfahmi, I.; Muliari, M.; Akmal, Y. and Batubara, A.S. (2018). Reproductive performance and gonad histopathology of female Nile tilapia (Oreochromis niloticus Linnaeus 1758) exposed to palm oil mill effluent. Egyptian Journal of Aquatic Research. 44: 327-332.

\section{ARABIC SUMMARY}

$$
\begin{aligned}
& \text { تأثير التلوث البيئى على أنسجة المناسل لأسماك البلطى النيلى }
\end{aligned}
$$

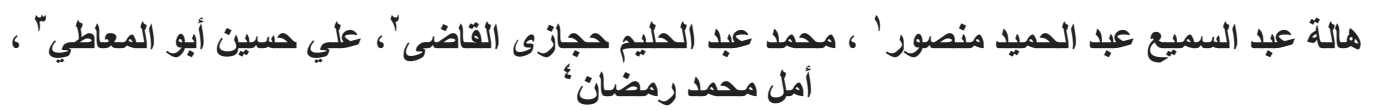

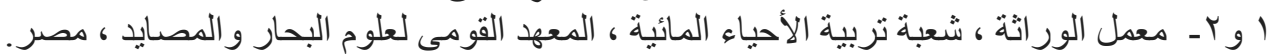

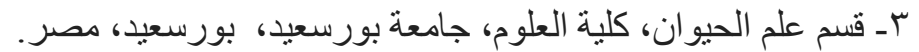

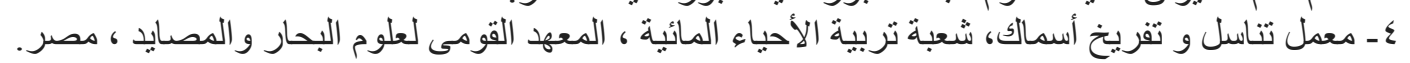

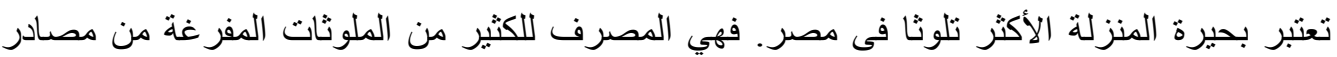

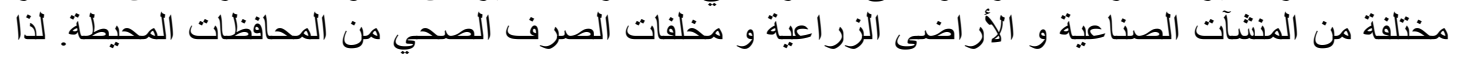

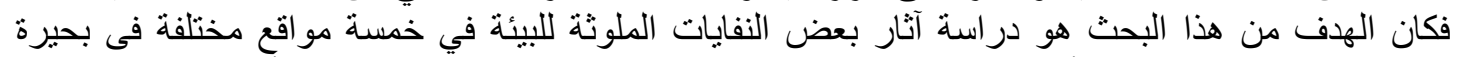

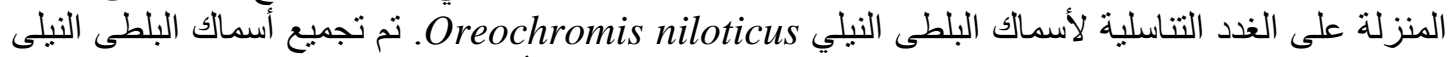

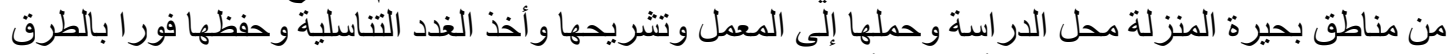

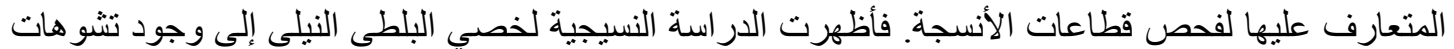

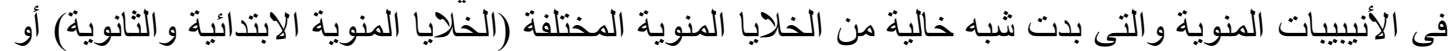

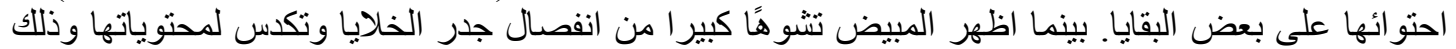

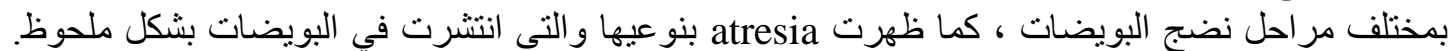

$$
\begin{aligned}
& \text { لذا أوصينا بزيادة مر اقبة جودة المياه و الرصد البيئي في بحيرة المنزلة. }
\end{aligned}
$$

